\title{
COPROLOGICAL AND SEROLOGICAL FINDINGS IN DOGS AND CATS WITH GIARDIOSIS AND CRYPTOSPORIDIOSIS
}

\author{
V. SVOBODOVÁ, J. KONVALINOVÁ, M. SVOBODA*
}

Department of Parasitology, and *Department of Internal Medicine, Faculty of Veterinary Medicine, Veterinary and Pharmaceutical University, 61242 Brno

Received September 5, 1995

\begin{abstract}
Svobodová V., J. Konvalinová, M. Svoboda: Coprological and Serological Findings in Dogs and Cats with Giardiosis and Cryptosporidiosis. Acta vet. Brno, 1995, 64: 257-262.

Giardia intestinalis and Cryptosporidium spp. findings in the faeces in dogs and cats, were compared with the incidence of specific antibodies in their blood sera. A total of 458 dogs and 135 cats were examined. Giardia intestinalis cysts and Cryptosporidium spp. oocysts were excreted by $25(5.5 \%)$ and $21(4.6 \%)$ dogs, respectively. Only $1(0.8 \%)$ cat excreted Giardia intestinalis cysts. Cryptosporidium spp. oocysts were excreted by $8(5.9 \%)$ cats. Specific Giardia intestinalis and Cryptosporidium spp. antibodies were detected in $167(36.5 \%)$ and $266(58 \%)$ dogs, respectively. In cats Giardia intestinalis and Cryptosporidium spp. antibodies were detected in 77 (57 \%) and $58(43 \%)$ animals, respectively.
\end{abstract}

Dog, cat, Giardia, cryptosporidia, cysts, oocysts, antibody, opportunistic infections

Giardiosis and cryptosporidiosis are parasitic diseases of protozoan origin which occur as opportunistic infections and, less frequently, as primary diseases. Their common characteristic is a low host specificity. Transmission between different animal species (Taminelli 1989, Pavlásek 1983) and man (Archibald et al. 1991; Casemore 1990) has been demonstrated and the diseases have been classified among zoonoses. The parasites are spread all over the world but their incidence varies from region to region, being particularly high in young subjects. In the human population the incidence of giardia was reported to amount to 2 to $6 \%$ in adults and to 10 to $15 \%$ in children in Central Europe (Giboda 1988). In subtropical and tropical areas it was found to be higher (Gilman et al. 1985; Eckert 1989). The incidence of cryptosporidia in humans was reported to be about 1 to $2 \%$ in adults and $4 \%$ in children in developed countries and may reach $30 \%$ or even more in developing countries (C a s e more 1990). In dogs and cats positive findings of giardia were found to range between 0.5 and $18 \%$ and between 2 and $3 \%$, respectively (Wolf and Eckert 1979; Jungmann et al. 1986; Swan and Thompson 1986). In our country Svobodová et al. (1987) and Vokoun (1988) recorded the incidence of cysts in faeces of dogs in $5.6 \%$ of the animals examined.

Cryptosporidium spp. oocysts were found, on average, in $2 \%$ of dogs (El-Ahraf et al. 1991) and 3,8 \% of cats (Uga et al. 1989, Arai et al. 1990). The spontaneous infection of cats with cryptosporidia was first confirmed in Japan (Iseki 1979). In our country the oocysts of cryptosporidia in cats were first diagnosed by Pavlásek (1985). The common feature of the two infections is that they affect particularly young subjects and are markedly related to the immune status. They are often asymptomatic and are the cause of longstanding disturbances of the gastrointestinal tract in young animals and immunodeficient patients.

The present study was focused on the incidence of giardiosis and cryptosporidiosis in dogs and cats because these animals live in close contact with humans and their families and may 
therefore come into account as potential sources of infection particularly for children and weakened subjects (Egger et al. 1990; Green et al. 1990; Svobodová et al. 1988).

\section{Materials and Methods}

A total of 458 dogs and 135 cats were subjected to coprological and serological examination. The animals under were either treated or hospitalized at the 1st Department of Internal Medicine of the University of Veterinary and Pharmaceutical Sciences, Brno. The dogs represented 49 breeds and crosses, the majority of them being German sheep-dogs, dachshunds and poodles. They were between 7 days and 16 years of age. About $71 \%$ of them came from urban environment (mostly Brno) and the remaining $29 \%$ were kept in the country. Included in this group were also police dogs, mainly German sheep-dogs. The cats represented 5 breeds and crosses, the majority of them being European short-haired cats and Persian cats. They ranged from 1 day to 12 years of age. The proportions of cats kept in urban environment (mostly Brno agglomeration) and in the country were 94 and $6 \%$, respectively.

Clinical examination was focused on detection of main symptoms with particular reference to digestive disorders. Results of supplementary examinations and diagnostic conclusions were taken over from case history notes recorded at the 1st Department of Internal Medicine. Faecal samples for parasitological examination were either obtained during hospitalization or brought along by the owners or taken by means of rectal rods. Coprological examination was carried out with the flotation method using saccharose solution of specific gravity of 1150 . The samples were examined with an optical microscope at the magnification of $200 x$ and $630 x$. For accurate differentiation of Cryptosporidium spp. oocysts use was made of differential staining according to $\mathrm{M}$ i 1 á $\mathrm{c}$ e $\mathbf{k}$ and Vít o vec(1985).

Blood samples for serological examination were withdrawn from the vena cephalica antebrachii or vena saphena in dogs and from the vena jugularis or vena cephalica antebrachii in cats. The sera were stored at $-20^{\circ} \mathrm{C}$ in plastic test-tubes. Serological examination was carried out with the indirect immunofluorescence method using freezedried antigammaglobulin conjugate for dogs and cats labelled with fluoresceinisothiocyanate prepared in cooperation with BIOVETA, Ivanovice na Hané. Corpuscular Cryptosporidium spp. antigen was obtained from positive calf faeces by repeated washing in buffered saline. Corpuscular Giardia intestinalis antigen was obtained from positive human faeces in a similar way. After being applied to slides, antigen was fixed with acetone and stored at $-20^{\circ} \mathrm{C}$. For the serological examination itself the sera were subjected to serial dilution starting at the titre of 10. Reliability of the serological reaction was checked by inclusion of the following controls: negative - without serum and with repeatedly negative sera; positive - with repeatedly positive sera. The reactions were evaluated under an immunofluorescence microscope at the magnification of $630 \times$.

\section{Results}

The dogs were found to be affected mostly with infectious diseases (distemper, parvovirosis). Parasite findings are shown in Table 1. Giardia intestinalis cysts were found in $25(5.5 \%)$ dogs and Cryptosporidium spp. 21 (4.6\%) dogs. Concurrent infection with the two parasite species was recorded in $7(10.6 \%)$ cases. Giardia intestinalis antibodies were detected in $167(36.5 \%)$ dogs at titres of 10 to 160 . The highest proportion of positive

Table 1

Survey of parasites found in the faeces of $\operatorname{dogs}(n=458)$

\begin{tabular}{|l|r|r|}
\hline \multicolumn{2}{|c|}{ Positive findings } \\
\hline Parasite species & No. & $\%$ \\
\hline Giardia intestinalis & 25 & 5.5 \\
Cryptosporidium sp. & 21 & 4.6 \\
Isospora ohiensis & 55 & 12.0 \\
Hammondia heydorni & 4 & 0.9 \\
Sarcocystis sp. & 2 & 0.4 \\
Toxocara canis & 74 & 16.2 \\
Toxascaris leonina & 3 & 0.7 \\
Trichuris vulpis & 5 & 1.1 \\
Ancylostoma caninum & 1 & 0.2 \\
Taenia sp. & 3 & 0.7 \\
Total & 193 & 42.3 \\
\hline
\end{tabular}


Table 2

Survey of parasites found in the faeces of cats $(n=135)$

\begin{tabular}{|l|r|r|}
\hline \multicolumn{2}{|c|}{ Positive findings } \\
\hline Parasite species & No. & $\%$ \\
\hline Giardia intestinalis & 1 & 0.7 \\
Cryptosporidium sp. & 8 & 5.9 \\
Ssospora felis & 14 & 10.4 \\
Ssospora rivolta & 5 & 3.7 \\
Toxoplasma gondii & 9 & 6.7 \\
Sarcocystis sp. & 4 & 3.0 \\
Toxocara cati & 24 & 17.8 \\
Toxascaris leonina & 1 & 0.7 \\
Total & 66 & 48.9 \\
\hline
\end{tabular}

findings $(60.9 \%)$ was found in the basic dilution of 1:10. Cryptosporidium spp. antibodies were found in $266(58 \%)$ dogs at titres of 10 to 1280 . The highest proportion of positive findings ( $29 \%$ ) was found in the basic dilution of 1:10. Comparison of the parasitological and serological findings is shown in Table 3. The relation between positive Giardia intestinalis and Cryptosporidium spp. findings in the faeces and specific antibody findings in the blood sera of dogs is shown in Fig. 1.

Table 3

Comparison of parasitological and serological findings in dogs $(n=458)$

\begin{tabular}{|l|ccrr|}
\hline Parasite species & $\begin{array}{c}\text { Parasitological } \\
\text { examination }\end{array}$ & $\begin{array}{c}\text { Serological } \\
\text { examination }\end{array}$ & No. & $\%$ \\
\hline Giardia & - & - & 316 & 69.2 \\
intestinalis & - & + & 117 & 25.4 \\
Cryptosporidium & + & - & 18 & 3.9 \\
parvum & + & - & 7 & 1.5 \\
& - & + & 188 & 41.0 \\
& + & + & 4 & 54.4 \\
& + & & 17 & 0.9 \\
\hline
\end{tabular}

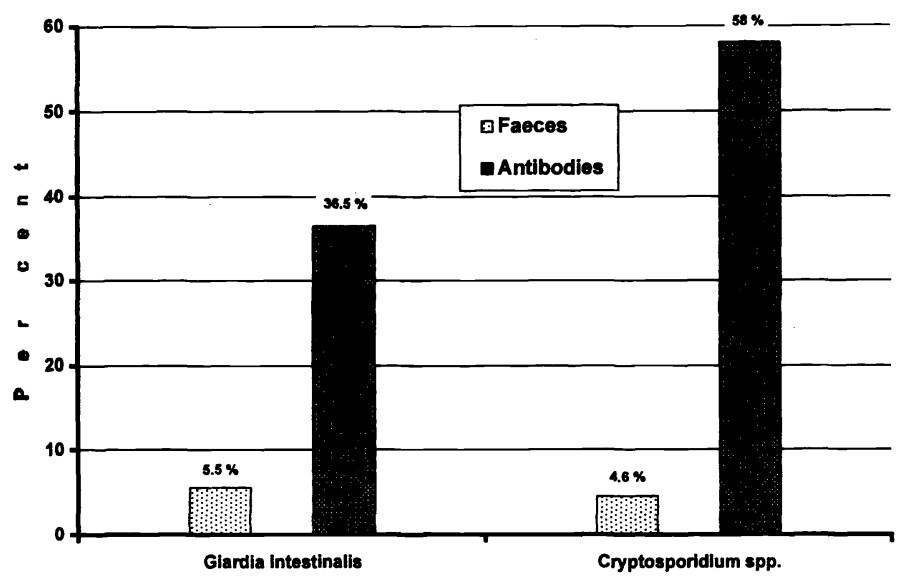

Fig. 1. Parasitological and serological findings in dogs 
The cats were affected mostly with diseases of parasitic origin. A survey of parasite findings is presented in Table 2. Giardia intestinalis cysts were found in $1(0.8 \%)$ cat and Cryptosporidium oocysts in $8(5.9 \%)$ cats.

Giardia intestinalis antibodies were detected in $77(57 \%)$ cat blood serum samples at titres of 10 to 320 . The highest proportion of positive findings $(29.9 \%)$ was found in the basic dilution of 1:10. Cryptosporidium spp. antibodies were detected in $58(43 \%)$ cats at titres of 10 to 160 . The highest proportion of positive findings $(47 \%)$ was recorded in the basic dilution of 1:10. Comparison of the parasitological and serological findings is shown in Table 4. The relation between positive Giardia intestinalis and Cryptosporidium spp. findings in the faeces and specific antibodies findings in the blood sera of cats is presented in Fig. 2.

Table 4

Comparison of parasitological and serological findings in cats $(n=135)$

\begin{tabular}{|l|ccrr|}
\hline Parasite species & $\begin{array}{c}\text { Parasitological } \\
\text { examination }\end{array}$ & $\begin{array}{c}\text { Serological } \\
\text { examination }\end{array}$ & No. & $\%$ \\
\hline Giardia & - & - & 61 & 45.2 \\
intestinalis & - & + & 73 & 54.1 \\
Cryptosporidium & + & - & 0 & 0 \\
parvum & + & - & 1 & 0.7 \\
& - & + & 72 & 53.3 \\
& + & + & 55 & 40.8 \\
& + & + & 3 & 3.7 \\
\hline
\end{tabular}

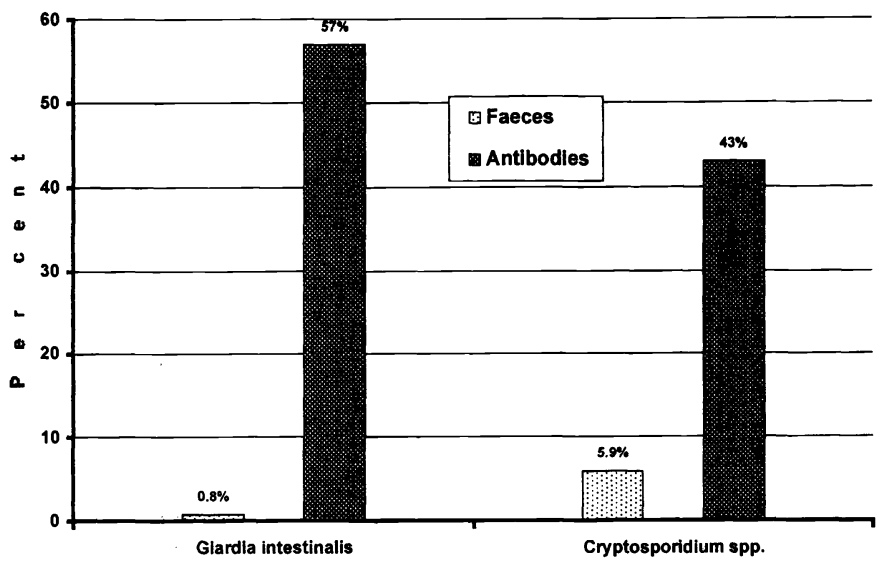

Fig. 2. Parasitological and serological findings in cats

\section{Discussion}

The present faecal findings of Giardia intestinalis cysts and Cryptosporidium spp. oocysts in dogs (5.5\% and $4.6 \%$, respectively) and cats (0.8\% and $5.9 \%$, respectively) are in keeping with the observations of Kulda and Nohýnková (1978), Wolf and Eckert (1979), Jungmann et al. (1986), Kirkpatrick (1986), Svobodová et al. (1987) a. o. who found giardia cysts in 0.5 to $18 \%$ of dogs and cats, with the incidence particularly high in the young. In their studies on the excretion of Cryptosporidium spp. oocysts from dogs and cats U g a et al. (1989), Arai et al. (1990) and El-Ahraf et al. (1991) found the 
oocysts mostly in 2 to $4 \%$ of the animals. Our present findings in dogs and cats are slightly higher for Cryptosporidium spp. (4.6 and $5.9 \%$ ) and also relatively higher for Giardia intestinalis, which can be accounted for by a greater proportion of young and diseased animals in our study. The same explanation can be offered for a higher incidence of Toxoplasma gondii oocysts in the faeces of our cats $(6.7 \%)$. The prevalence of parasitic infections has been found to increase with the number of animals kept together in reduced space. Hořej§ and Koudela (1994) found giardia cysts in as many as $36.2 \%$ of faecal samples from police dogs kept together at a breeding station. In the dogs and cats included in our study giardiosis and cryptosporidiosis were present as typical opportunistic infections accompanying major primary diseases with a number of immunosuppressive factors (distemper, parvovirosis, demodicosis, neoplasia). The clinical symptoms were nonspecific, the prevailing signs being diarrhoea and body wasting and, in acute cases, subsequent dehydration. These symptoms were often overlaid by the primary disease. Marked clinical signs may be due to combined effects of further conditionally pathogenic factors. In both dogs and cats included in our study the number of serologically positive animals increased with age which suggests possible repeated infection during their life time. The infection is often latent in form or opportunistic without direct demonstration of Cryptosporidium spp. oocysts or Giardia intestinalis cysts, with specific antibodies persisting for several months and rising in titre upon reinfection. Our results confirmed that giardiosis and cryptosporidiosis are protozoan infections showing no marked clinical manifestations. Nevertheless, they play a certain role in relation to human population. Their incidence in both animals and man depends particularly on the immune status of the subject.

\section{Koprologické a serologické nálezy při giardióze a cryptosporidióze psů a koček}

Srovnávali jsme nálezy Giardia intestinalis a Cryptosporidium spp. v trusu s výskytem specifických protilátek v krevním séru psů a koček. Celkem jsme vyšetřili 458 psů a 135 koček. Cysty r. Giardia vylučovalo 25 psủ $(5,5 \%)$ a oocysty r. Cryptosporidium 21 psů $(4,6 \%)$. Pouze 1 kočka vylučovala cysty r. Giardia $(0,7 \%)$. Oocysty r. Cryptosporidium byly zjištěny u 8 koček $(5,9 \%)$. Specifické protilátky proti $G$. intestinalis byly detekovány u 167 psů $(36,5 \%)$ a proti Cryptosporidium spp. ve $266(58 \%)$ psů. U koček byly protilátky proti G. intestinalis prítomny u 77 jedinců $(57 \%)$ a proti Cryptosporidium spp. u 58 koček $(43 \%)$.

\section{References}

ARAI, H., FUKUDA, T., HARA, T., FUNAKOSHI, Y., KANEKO, S., JOSHIDA, T., ASAHI, H., KUMADA, M., KATO, K., KOYAMA, T. 1990: Prevalence of Cryptosporidium infection among Domestic Cats in Tokyo Metropolitan District, Japan, Jpn. J. Med. Sci. Biol. 43: 7-14

ARCHIBALD, S. C., MITCHELL, R. W., UPCROFT, P. F., BOREHAM, L., UPCROFT, P. 1991: Variation between Human and Animal Isolates of Giardia as Demonstrated by DNA Fingerprinting. Int. J. Parasitol. 21: $123-124$

CASEMORE, J. P. 1990: Epidemiological aspects of human cryptosporidiosis. Epidemiol. Infect. 104: 1-28

ECKERT, J. 1989: New aspects of parasitic zoonoses. Vet. Parasitol. 32: 37-55

EGGER, M., MAI NGUYAN, X., SCHAAD, V. B., KRECHT, T. 1990: Intestinal Cryptosporidiosis Acquired from a cat. J. Clin. Stud. and Treatment of Infections, 18: 177-178

EL-AHRAF, A., TACAL, J. V. Jr., SOBIH, M., AMIN M., LAWRENCE, W., WILCKE, B. W. 1991: Prevalence of cryptosporidiosis in dogs and human beings in San Bernardino Country, California. JAVMA 198: 631-634

GIBODA, M. 1988: Jednobuněcní paraziti lidského střeva. Avicenum, Praha, p. 65-71

GILMAN, R. H., BROWN, K. H., VISVESVARA, G. S., MONDAL, G., GREENBERG, B., SACK BRADLEY, R., BRANDT, F., KHAN, M. U. 1985: Epidemiology and serology of Giardia lamblia in a developing country: Bangladesh. Transactions of the Royal Society of Tropical Medicine and Hygiene 71: 469-473

GREEN, E., WARHURST, D., WILLIAMS, J., DICKENS, T., MILES, M. 1990: Application of a Capture Enzyme Immunoassay in a Outbreak of Waterborne Giardiasis in the United Kingdom. Eur. J. Clin. Microbiol. Infect. Dis. 9: $424-428$ 
HOREJŠ, R., KOUDELA, B. 1994: Giardióza psủ v chovné stanici. Vet. Med. - Czech 39: 93-101

ISEKI, M. 1979: Cryptosporidium felis sp. m. (Protozoa: Eimeriorina) from cat. Jpn. J. Parasitol. 28: 285-307

JUNGMANN, R., HIEPE, Th., SCHEFFLER, C. 1986: Zur parazitären Intestinal fauna bei Hund und Katze mit einem speziellen Beitrag zur Giardia Infection. Mh. Vet. Med. 41: 309-311

KIRKPATRICK, C. E. 1986: Feline giardiasis: a review. J. Small Anim. Pract. 27: 69-80

KULDA, J., NOHÝNKOVÁ, E. 1978: Flagellates of the Human Intestines and Intestines of Other Species. In: Parasitic Protozoa II. (KREIER, J. edit.) Academic Press, New York, p. 6-104

PAVLÁSEK, I. 1983: Experimental infection of cat and chicken with Cryptosporidium sp. oocysts isolated from a calf. Folia parasitol. (Praha) 30: 121-122

PAVLÁSEK, I. 1985: První nález spontánní kryptosporidiózní infekce kočky domácí v ČSSR. Veterinášství 35: 3

SVOBODOVÁ, V., SVOBODA, M., NEVOLE, M. 1987: Giardióza u psủ. Veterináł̌ství 37: 506-508

SVOBODOVÃ, V., NEVOLE, M. 1988: Druhová specifita rodu Giardia. Referát na konferenci „Problematika humánní parazitologie“, Zprávy Ceskoslovenské společnosti parazitologické 28/3: 26

SWAN, J.M., THOMPSON, R. C. A. 1986: The prevalence of Giardia in dogs and cats in Perth, Western Australia. Austr. Vet. J. 63: 110-112

MILÁĆEK, P., VITOVEC, J. 1985: Differential staining of Cryptosporidia by aniline-carbol-methyl violet and tartrazine in smears from faeces and scrapings of intestinal mucosa. Folia parasitol. (Praha) 32: 50

TAMINELLI, V., ECKERT, J., SYDLER, T., GOTTSTEIN, L., CORBOZ, L., HOFMANN, M. 1989: Experimentelle Infektion von Kälbern und Schafen mit bovinen Giardia-Isolaten. Schweiz. Arch. Tierheilk. 131: 551-564

UGA, S., MATSUMURA, T., ISHIBASHI, K., YODA, Y., YATOMI, K., TAKAOKA, N. 1989: Cryptosporidiosis in dogs and cats in Hyogo Prefecture, Japan. Jpn. J. Parasitol. 38: 139-143

VOKOUN, P. 1988: Ke giardióze psủ a kơek. Veterináłství 38: 505-507

WOLF, K., ECKERT, J. 1979: Giardia - Befall bei Hund und Katze und dessen mögliche Bedeutung für den Menschen. Berl. Münch. Tierärztl. Wschr. 92: 484-490 